\title{
KAJIAN TEOLOGIS MENGENAI PRAKTIK OKULTISME DAN PELAYANAN PELEPASAN BAGI MAHASISWA
}

\author{
Elfrida Saragih, Ebenhaizer I Nuban Timo \\ Faculty of Theology, Satya Wacana Christian University, Salatiga-Indonesia \\ Email: elfrida.saragih@gmail.com, ebenhur65@yahoo.co.id
}

\begin{abstract}
Types of occultism practices in the society were trusting in the spirit of the dead, a talisman which was considered to have the power to keep the body, and the science of strength given by the ancestors to offspring. So that made offspring suffer from frequent manifestations and was possessed by an evil spirit. This article examines that issues. Theory about the exorcist services by Graham $\mathrm{H}$. Twelftree the theoretical frame observe carefully these problems. Methods of this research was the direct involvment method by viewing, serving and interviewing the people who involved in the power of the occult. This research was conducted in STT Abdi Sabda Medan. Three things that invited by researcher are first, which causes people involved with occultism practices. Secondly, due both to the occult practices and to their descendants who are having a negative impact, they often encounter manifestations of evil spirits also stressed physically, psychologically and spiritually. Third, efforts to heal and cure that people from the occult is exorcist services.
\end{abstract}

Keywords: Occultism, exorcist services, Manifestation, the Spirit of Evil

\begin{abstract}
ABSTRAK: Okultisme adalah kepercayaan mengenai kuasa-kuasa gelap yaitu kekuatan gaib di luar kekuatan Tuhan.Jenis praktik okultisme yang terdapat pada masyarakat ialah kepercayaan terhadap roh orang mati, jimat yang dianggap memiliki kesaktian untuk menjaga badan, dan ilmu kekebalan yang diberikan oleh nenek moyang kepada keturunannya, sehingga membuat keturunannya menderita karena sering manifestasi dan dirasuki oleh roh-roh jahat. Artikel ini mengkaji persoalan tadi.Teori mengenai pelayanan eksorsis oleh Graham H.Twelftree dalam bingkai teoritis meneropong permasalahan tersebut.Metode penelitian yang penulis lakukan untuk menulis artikel ini adalah keterlibatan langsung melihat, melayani dan interview kepada mereka yang terlibat kuasa okultisme. Penelitian ini dilakukan di STT Abdi sabda Medan, Tiga hal yang menjadi temuan penelitian: Pertama, yang menyebabkan orang terlibat dengan praktik okultisme adalah karena diturunkan oleh nenek moyang yang melakukan praktik okultisme. Kedua, akibat praktik okultisme baik terhadap orang yang melakukan dan terhadap keturunannya adalah memiliki dampak negatif, mereka akan sering mengalami manifestasi roh-roh jahat juga tertekan secara fisik, psikologis dan secara rohani. Ketiga, Upaya yang dapat dilakukan untuk menyembuhkan dan memulihkan seseorang agar terlepas dari kuasa okultisme adalah melalui pelayanan eksorsis.
\end{abstract}

Keywords: Okultisme, Pelayanan Pelepasan, Manifestasi, Roh Jahat

\section{PENDAHULUAN}

Dalam praktiknya, okultisme yaitu praktikpraktik yang dilakukan denganrahasia dan latar belakang di luar logika manusia dengan peristiwa yang gaib dan aneh. Pelaku okultisme mengarah kepada sebuah hasrat untuk memiliki atau menguasai atau menginginkan sesuatu atau juga merupakan praktik akibat takut terhadap sesuatu kutukan sehingga melakukan tindakan okultisme. Banyak tindakan olkultisme yang kesemuanya ini pada umumnya adalah warisan dari nenek moyang turuntemurun. Jika ditanya kenapa timbul kepercayaan terhadap kuasa kegelapan atau okultisme di kalangan masyarakat sekarang? Hal ini memiliki hubungan dengan kepercayaan akan okultisme itu di kalangan masyarakat suku primitif (manusia pada zaman sebelum sekarang).

Jenis praktik okultisme yang terdapat pada masyarakat sekarang ini ialah spiritisme, ilmu ramal atau tenung, ilmu sihir/magi, ilmu hitam (black 
magic), ilmu putih (white magic), jimat-jimat yaitu barang atau sesuatu benda yang mereka percayai memiliki kuasa atau mengandung kesaktian dan dianggap berjiwa dan pada umumnya jimat ini dipakai untuk penjagaan diri, pencapaian cita-cita atau penangkal/penakluk terhadap lawan. Tentu masih banyak lagi praktik-praktik okultisme yang sering dilakukan oleh orang walaupun dalam konteks masyarakat zaman modern sekarang ini khususnya juga di kalangan masyarakat yang tinggal di desa. Kuasa kegelapan bekerja dan memanifestasikan pengaruh dalam berbagai bentuk, dari yang sederhana sampai kepada yang luar biasa yang membuat orang terheran-heran dan terpikat, dari cara yang kuno sampai kepada cara yang modern, yang membuat kuasa kegelapan memasuki semua jenis lapisan masyarakat, mulai dari yang primitif sampai kepada golongan intelektual (para pejabat). Kuasa kegelapan juga memanifestasikan diri dalam berbagai nama, misalnya: Jin, roh halus, hantu dan lain sebagainya. Dan hadir diberbagai tempat dan bisa ditemukan diberbagai media, benda-benda, binatang bahkan melalui manusia yang mengakibatkan manusia tertipu. Ada anggapan bahwa berhubungan dengan roh tertentu bukan sesuatu yang salah.(Wulfhost, 2005, p. 41)

Hal ini juga yang sering penulis temui, bahkan sejak ambil bagian dalam Tim Pelayanan Pelepasan(Deliverence Ministry Team)selama 7 tahun lebih, sering atau bahkan banyak menemukan kasus-kasus yang demikian. Secara khusus ketika kami melakukan pelayanan pelepasan setiap tahun di STT Abdi Sabda tempat ketika penulis dulu menyelesaikan studi Sarjana (S-1). Setiap tahun dalam pelayanan pelepasan untuk mahasiswa baru ada banyak mahasiswa yang mengalami manifestasi dalam pelayanan pelepasan tersebut dan mereka yang mengalami manifestasi biasanya ada yang saling beradu atau saling serang satu dengan yang lain, ada yang melompat-lompat sampai ke atas dan menjatuhkan dirinya sehingga tidak jarang fasilitas seperti kursi plastik akan pecah atau hancur, ada juga yang muntah-muntah, berteriak-teriak, menyiksa dirinya sendiri bahkan melakukan serangan terhadap tim yang melayaninya itulah sebabnya untuk melayani seorang yang kena manifestasi dibutuhkan tim sebanyak tiga atau empat orang dimana sebahagian dari tim memeganginya dan sebahagian mendoakannya.

Tujuan penelitian ini adalah 1) untuk menemukan faktor yang menyebabkan orang terlibat dengan praktik okultisme atau kuasa kegelapan; 2) untuk mengetahui dampak atau akibat yang ditimbulkan dari praktik okultisme terhadap seseorang yang melakukannya dan terhadap keturunannya; 3) untuk memaparkan upaya yang dapat dilakukan untuk menyembuhkan atau memulihkan seseorang agar terlepas dari praktik okultisme.

\section{METODE}

Penelitian ini dilakukan di STT Abdi sabda Medan, metode penelitian ini adalah kualitatif dengan cara melakukan analisa terhadap data-data hasil penelitian serta studi literatur terkait. Teknik pengumpulan data yang dilakukan dalam penelitian ini adalah pengamatan dengan keterlibatan langsung melihat, melayani mereka yang terlibat kuasa kegelapan. Selain itu juga penelitian ini melalui studi kepustakaan yakni dengan cara penulis mencari dan mengambil data-data dari buku, artikel dan tulisantulisan yang berkaitan dengan artikel ini.

\section{HASIL DAN PEMBAHASAN}

Menurut Kamus Besar Bahasa Indonesia, istilah okultisme berarti kepercayaan kepada kekuatan gaib yang dapat dikuasai manusia (Alwi, 1987, p. 795). Pondsius dan Susanna Takaliung mengatakan okultisme berasal dari kata Occult dan Isme. Occult artinya gelap dan isme: artinya paham atau ajaran. Jadi okultisme berarti paham atau kepercayaan mengenai kuasa-kuasa gelap, kekuatan gaib diluar kuasa Tuhan (Pondsius \& Takaliung, n.d. p, 8). Dalam Handbook of today's Religion okultisme dijelaskan sebagai hal-hal yang bersangkut paut dengan hal-hal yang rahasia (things secret or hidden) dan supranatural dan ditandai dengan kehadiran kuasa jahat (the presence of demonic forces). 
Jadi Okultisme dapat diartikan sebagai kepercayaan kepada roh-roh di alam ini yang bisa menolong, memberkati, menyakiti bahkan membunuh, memberi keberuntungan, menyebabkan ketakutan, yang mempengaruhi manusia untuk memujanya. Praktik okultisme itu adalah sesuatu yang rahasia (secret) atau hidden from ordinary people (tersembunyi dari manusia biasa). Okultisme juga sesuatu yang magical and mysterious (magis dan misteri).

\section{Latar Belakang Praktik Okultisme dan Teori Mengenai Okultisme}

Salah satu bentuk kepercayaan agama suku yang masih mempunyai pengaruh yang besar sampai hari ini adalah kepercayaan terhadap roh orang yang sudah mati. Herbet Spenser (1820-1903) seorang filsuf dan sosiolog asal Inggris menegaskan bahwa agama-agama pada mulanya berasal dari kultus penghormatan kepada leluhur (Spencer, 2009, p. 19). Pada umumnya di setiap agama suku ada kepercayaan bahwa roh orang yang mati masih berada di dunia ini dan masih mempunyai hubungan dengan orang yang hidup. Khususnya kepercayaan bahwa roh nenek moyang (leluhur) masih mempunyai hubungan dengan keturunannya yang masih hidup dalam berbagai manifestasi, yang akan memberi berkat (fortune) jika dihormati dan mengakibatkan malapetaka (misfortune) jika diabaikan. Juga adanya kepercayaan bahwa roh yang sudah mati ada yang menjadi roh yang baik yang diyakini dapat memenuhi keinginan misalnya: memberi keberuntungan, kesuburan, melindungi dari bahaya dan roh nenek moyang diyakini sebagai roh yang baik yang memperdulikan kesejahteraan keturunannya. Dan roh yang jahat yang diyakini mendatangkan bahaya, bencana, penyakit, wabah, kerasukan dan kematian.(Wulfhost, 2005, p. 19). Hal ini mengakibatkan adanya sikap ketakutan terhadap roh yang jahat dan berusaha mendapatkan perlindungan melalui dukun (medium), dan terhadap roh yang baik memelihara sikap hormat dan berterima kasih yang dinyatakan dengan berbagai cara.
Seperti yang dijelaskan Krisnando dkk dalam konteks agama suku Batak yang mempunyai pengaruh besar sampai saat ini adalah adanya kepercayaan bahwa roh orang mati khususnya roh nenek moyang yang sudah menjadi falsafah orang Batak yaitu, Hagabeon (banyak keturunan), Hamoraon (kekayaan) dan Hasangapon (kemuliaan), berubah menjadi sumangot (suatu kekuatan atau kuasa yang bisa melakukan sesuatu) kepada keturunannya yang masih hidup. Keyakinan ini diungkapkan dengan istilah martondi namangolu marsumangot namate artinya yang hidup mempunyai roh dan sesudah mati rohnya berubah menjadi sumangot dan juga menjadi begu (hantu). Hal ini dijelaskan karena orang Batak percaya bahwa jika seseorang telah meninggal, maka "daging gabe tano, hosa gabe alogo, tondi gabe begu” yang artinya daging jadi tanah, nafas jadi angin, roh jadi hantu. (Krisnando, Objantoro, \& Darmawan, 2019, p. 92)

Hutapea (2019, p. 91-92) juga mengatakan sebahagian orang Batak sampai saat ini masih mempercayai roh-roh nenek moyang mempunyai kuasa atau kekuatan untuk dapat menolong, melindungi, memberikan berkat bagi keturunannya karena itu tidak jarang jika orang Batak ziarah ke makam leluhur atau nenek moyangnya maka akan membawakan sesajen berupa sirih, makanan kesukaan nenek moyangnya atau makanan khas suku Batak, memberikan rokok dan benda-benda lain dikuburan nenek moyang dengan alasan bahwa agar roh nenek moyang itu merokok, makan sirih dan makan-makanan yang diletakkan dikuburannya, menggali tulang belulang dan mendirikan tugu-tugu kuburan serta membuat pesta tugu tersebut karena takut jika tidak dilakukan demikian maka roh nenek moyang yang sudah meninggal akan marah. Selain itu orang Batak memiliki pemahaman dengan melakukan hal tersebut maka roh nenek moyang tersebut dapat memberikan berkat kepada keluarga dan keturunannya. Hutapea dalam bukunya juga mengatakan masih jelas terlihat sebahagian orang Batak masih sangat terikat terhadap roh orang yang sudah meninggal, itu sebabnya masih gampang iblis menipu 
orang Batak dengan cara kesurupan, banyak orang percaya bahwa yang kesurupan itu adalah roh orang yang sudah meninggal. Sesungguhnya iblis yang menyamar dengan menggunakan cara dan ciri orang yang meninggal, tetapi hal demikian sangat kental dipercaya oleh sebahagian orang Batak Kristen (Hutapea, 2019, p. 91-92).

Hutapea juga dalam bukunya mengatakan bahwa faktor-faktor yang menyebabkan orang terlibat dengan praktik okultisme adalah Pertama, untuk menghormati orang tua karena alasan menghormati dan taat kepada orang tua maka menerima pusaka dan jimat-jimat yang diberikan orang tua untuk perlindungan. Kedua, karena takut roh orang yang sudah meninggal marah, biasanya karena takut pada roh orang yang meninggal marah maka sering melayani dengan memberikan dan melakukan sesuatu kepada orang yang sudah meninggal melalui pemberian sesajen dan berdoa dikuburan untuk meminta supaya roh yang sudah meninggal itu tidak mengganggu dan tidak marah, karena jika roh orang yang sudah meninggal itu marah menurut mereka dapat menimbulkan berbagai masalah dan wabah penyakit. Ketiga, karena dukun memakai hal-hal yang rohani, dukun juga sering memakai hal-hal atau benda-benda rohani yang justru biasanya digunakan untuk pelayanan rohani seperti Alkitab, salib, lilin, roti dan anggur perjamuan kudus sehinga hal ini mengakibatkan banyak orang beranggapan bahwa hal itu berasal dari Tuhan. Keempat karena mendatangkan keuntungan dan pertolongan. Kelima, karena tuntutan adat istiadat, sebab adat istiadat sering bercampur dengan praktik okultisme dan dipakai Iblis untuk menipu manusia. Keenam, karena ada bukti-bukti yang meyakinkan, dan Ketujuh, karena didorong oleh ketakutan yaitu mereka menggunakan jasa kuasa kegelapan karena takut setan mengganggu hidupnya segingga mencari pertolongan dari kuasa kegelapan (Hutapea, 2019, p. 99-104).

Surya Kusuma dalam bukunya "Okultisme : Antara Budaya vs Iman Kristen”, menuliskan beberapa alasan yang mempengaruhi seseorang melakukan praktik okultisme ialah pertama, pemahaman yang salah tentang Allah. Konsep-konsep yang salah tentang eksistensi, jati diri, kuasa Allah yang transenden sulit dipahami penuh misteri dan tidak terselami sehingga mendorong manusia berupaya mencari dan berkomunikasi dengan Allah melalui berbagai cara yaitu tirakat, belajar berbagai mantera, spiritisme, dan mempersonifikasikan Allah menjadi mahluk, materi atau benda-benda ciptaan untuk disembah dan dipuja. Kedua, perasaan tidak berdaya ditengah alam semesta. Manusia menyadari dirinya terbatas, lemah, dan tak berdaya di tengah alam semesta yang penuh misteri dan aneka ragam permasalahan kehidupan sehingga membawa manusia untuk mencari dan menemukan kuasa yang dapat menjamin, melindungi dan menanggulagi berbagai kondisi yang ditemui dalam kehidupan di alam semesta, hal inilah yang mendorong manusia untuk mencari kesaktian, berbagai jimat, mantera serta ramalan dan berbagai ilmu penolak bala. Ketiga, usaha manusia untuk memperoleh hidup aman, tenang dan damai. Di tengah-tengah hidup yang penuh dengan kesulitan, bencana, musibah, tragedi dan aneka ragam bahaya untuk mengantisipasi semua permasalahan tersebut manusia mendalami berbagai hal seperti ilmu ramal, horoskop, astrologi, pitungan, garis tangan dan hal lainnya, tujuannya agar mereka terhindar dari ancaman-ancaman yang sewaktu-waktu menimpa hidup mereka. Keempat, kehendak hidup sehat, awet muda, dan panjang umur. Kehendak hidup sehat, awet muda dan panjang umur yang membuat seseorang menggunakan susuk yang juga adalah bagian dari praktik okultisme. Kelima, persaingan, musuh dan bahaya.negatif. Perjuangan untuk mengalahkan dan menghancurkan para pesaing, musuh-musuh dan bahaya menarik orang-orang terlibat ke dunia okultisme seperti tenung, santet, dan magi untuk melindungi diri atau menyerang orang lain. Keenam, nafsu memperoleh kekayaan dan materi berlimpah. Ketujuh, peningkatan daya pesona dan pemuasan nafsu. Ilmu tenung dan sihir dimanfaatkan oleh orang tertentu agar mereka memiliki daya pesona, daya rangsang dan kepuasan 
seksual baik bagi dirinya maupun bagi orang yang mencarinya (Kusuma, 2010, p. 8-11).

Dampak dari mereka yang melakukan praktik okultisme adalah secara fisik yaitu urat-urat syaraf terganggu. Secara psikologi yaitu mengalami depresi, ketakutan yang tidak normal dan memiliki pikiran-pikiran najis. Secara rohani yaitu mati secara rohani dan sikap tertutup terhadap Firman Tuhan, malas berdoa, ragu terhadap Firman Tuhan dan ingin menghujat nama Tuhan. Dampak bagi keturunan yaitu keturunannya akan menjadi terkutuk,Alkitab menyaksikan itu sampai keturunan ketiga dan keempat (Keluaran 20), kutuk dari Allah akan mengakibatkan berbagai hal buruk, seperti munculnya berbagai kesulitan dan penyakit serta penderitaan bagi keturunan. Dampak kepada kekekalan yaitu seperti dalam Firman Tuhan di Galatia 5:20-21 maka tidak akan dapat bagian dalam kerajaan Allah jika tidak mengalami pertobatan.(Hutapea, 2019, p. 105).

Selanjutnya menurut Hutapea untuk memulihkan dan menyembuhkan mereka dari kuasa okultisme karena praktik-praktik okultisme yang dilakukan adalah dengan melakukan pelayanan pelepasan dan mengusir roh-roh jahat dari mereka yang terikat kuasa okultisme. Pelayanan pelepasan adalah salah satu amanat agung Yesus Kristus (Mat.10:8, Mrk.6:7), pelayanan pelepasan sangat penting dalam pelayanan gereja Tuhan di dunia ini. Hanya melalui pelayanan pelepasan orang yang terikat kuasa okultisme dapat dibebaskan, mengalami kesembuhan dan menikmati pertumbuhan di dalam Tuhan (Hutapea, 2019, p. 115)

Pondsius dan Takaliung dalam bukunya mengenai “Antara Kuasa Gelap dan KuasaTerang” juga mengatakan bahwa faktor-faktor yang menyebabkan orang terlibat praktik okultisme adalah Pertama, karena menghormati orang tua supaya panjang umur, iblis sering menggunakan ayat Firman Tuhan dalam Keluaran 20:12 yang mengatakan hormatilah ayah dan ibumu, supaya lanjut umurmu, kita memang wajib menghormati orang tua namun kita harus menolak permintaan atau desakan mereka untuk memegang jimat dan membawa kita ke dukun dan menduakan Tuhan. Kedua, karena takut kepada amarah orang yang sudah meninggal, orang melakukan praktik okultisme adalah untuk melayani orang mati baik roh orang tua maupun roh nenek moyang supaya mereka tidak marah terhadap anak-anak dan cucu-cucunya yang masih hidup. Ketiga, karena dukun memakai hal-hal rohani dan benda-benda rohani, dukun juga memakai hal-hal rohani seperti Alkitab, salib, lilin, sisa roti dan sisa anggur maka banyak orang yang menyangka bahwa hal itu berasal dari Tuhan padahal hal tersebut merupakan tipu muslihat. Keempat, kerena mendatangkan pertolongan yang menguntungkan, orang menghalalkan praktik okultisme karena mendatangkan keuntungan besar baik uang, harta, kedudukan, kekuasaan maupun kesembuhan dan sukses serta mujizat yang spektakuler dan yang lain-lainnya namun seharusnya tidak boleh tertipu karena keuntungan dari iblis pada hakikatnya adalah bencana besar, iblis tidak pernah memberikan pertolongan yang cuma-cuma, dia meminta bayaran yaitu jiwa. Kelima, karena tuntutan adat istiadat, yaitu adat istiadat yang melawan Firman Allah dan adat istiadat kafir yang dicampur dengan Firman Allah (Pondsius \& Takaliung, n.d. p, 195)

Selanjutnya Pondsius dan Takaliung juga mengatakan akibat bagi yang melakukan praktik okultisme adalah Pertama, akibat secara rohani yaitu tertutup keras terhadap Firman Allah.Kedua, akibat secara psikologi atau mental yaitu depresi, adanya ketakutan yang tidak normal, kemarahan yang tidak normal.Ketiga, akibat secara fisik yaitu urat syaraf sakit karena mempraktikkan okultisme secara aktif dan kematian yang tidak wajar. Keempat, akibat dalam keluarga yaitu kekacauan terjadi dalam keluarga karena roh pengacau diberi tempat dalam keluarga sehingga semuanya menjadi kacau dan berantakan. Kelima, akibat untuk keturunan berikutnya yaitu keturunan menjadi kacau dan terkutuk, tidak normal, cacat, sial dan mendapat hukuman turun-temurun (Kel. 20:4-5). Keenam, akibat untuk kekekalan yaitu orang yang terlibat okultisme tidak 
akan mewarisi kerajaan Allah (Gal. 5:20-21). (Pondsius \& Takaliung, n.d. p, 299)

Menurut Pondsius dan Takaliung upaya yang dapat dilakukan untuk memulihkan mereka agar tidak terikat dengan kuasa okultisme yaitu melalui pelayanan pelepasan dari belenggu okultisme sehingga mereka yang terikat okultisme dibebaskan secara tuntas dan benar-benar pulih (Pondsius \& Takaliung, n.d. p, 305). Jadi apa yang dikatakan oleh Hutapea mengenai faktor-faktor orang melakukan praktik okultisme, dampak atau akibat praktik okultisme dan upaya yang dilakukan untuk memulihkan atau melepaskan mereka dari kuasa okultisme sama dengan apa yang dikatakan oleh Pondsius dan Takaliung dalam bukunya.

Alkitab menandaskan ada dua kuasa yang sedang bekerja di dunia yaitu : kuasa terang (Allah) dan kuasa kegelapan (Iblis) dalam segala manifestasinya (1 Yoh.1:5-6, Yoh.8:12, Ef.5:8, 1 Pet.2:9). Maka dapat dikatakan bahwa segala sesuatu yang berada dalam kekuasaan Allah "Kerajaan Allah atau kuasa terang" dan segala sesuatu yang di bawah kekuasaan Iblis adalah "kerajaan Iblis atau kuasa kegelapan", di mana iblis yang menjadi raja atau penghulunya (Prience, 2002.p. 13). Kuasa Allah (terang) telah mengalahkan kerajaan iblis (gelap), namun iblis masih berkuasa dan berusaha dengan berbagai strateginya untuk menghambat orang di dalam kerajaannya (kegelapan) untuk masuk dalam kerajaan Allah (terang) dan berusaha memerangi orang yang sudah berada dalam kerajaan Allah (orang yang sudah percaya). Itulah sebabnya orang yang sudah percaya menghadapi peperangan rohani yaitu berperang dengan Iblis dengan segala antekanteknya yang disebut kuasa kegelapan, roh-roh jahat, penghulu-penghulu dunia yang gelap (Ef.6:12, 1 Pet.5:8). Iblis tidak hanya menggoda dan menyesatkan orang tetapi juga merasuk, menyiksa atau menyakiti dengan berbagai tipu dayanya, dengan menawarkan berbagai pertolongan yang membuat manusia tidak berdaya melepaskan dirinya dari kuasa kegelapan atau iblis (Pasaribu, 2002, p. 35). Banyak contoh-contoh kita temukan di dalam
Alkitab di mana orang-orang yang dirasuk setan dan yang terikat dengan kuasa kegelapan mengalami berbagai penderitaan. Ketidakpercayaan atau ketidaktahuan tentang pekerjaan iblis, membuat banyak orang termasuk orang kristen tertipu, dirasuk dan terikat dengan kuasa kegelapan (Sappington, 1998, p. 10).

Dari sebuah artikel yang berisikan hasil penelitian oleh Ward, dan Beaubrun mengenai The Psycodynamic of Demon Possesion di Afrika tepatnya bagi masyarakat Trinidad yang menyebabkan orang terikat dengan kuasa okultisme adalah karena masyarakat di sana masih banyak melakukan penyembahan terhadap nenek moyang, selain itu kelompok masyarakat di Trinidad masih sering pergi ke peramal yang disebut lookermen dan lookerwomen (peramal laki-laki dan perempuan) untuk mengetahui masa depan mereka. Mereka juga berkonsultasi kepada dukun (obeahmen) untuk mendapatkan perlindungan, memperoleh jimat, menyembuhkan orang atau melakukan pembalasan dendam. Dan masih banyak diantara masyarakat di Trinidad jika sakit pergi ke dukun untuk berobat, walaupun setelah berobat ke dukun mereka hanya mengalami kesembuhan sementara dan setelah itu penyakit mereka akan kambuh lagi dan semakin parah bahkan sering mengalami manifestasi. Ada empat kasus di Afrika didapat dari hasil penelitian dalam sebuah artikel yang mengatakan bahwa ke keempat kasus tersebut ketika mengalami sakit dan kerasukan mereka pergi berobat ke dukun yang disebut obeahman dan obeahwomen, setelah berobat ke obeahman dan obeahwomen biasanya mereka sembuh namun hanya sementara saja dan justru akibatnya setelah mereka berobat ke dukun adalah mereka kembali mengalami kerasukan yang lebih parah. Upaya yang dilakukan untuk memulihkan mereka adalah degan membawa mereka ke gereja pentakosta di Trinidad dan dilayani di gereja tersebut melalui pelayanan eksorsis, ada yang dilayani sampai 32 kali, 100 kali, dan 3 kali pelayanan eksorsis. Di gereja pentakosta tersebut mereka mengalami mujizat pemulihan melalui pelayanan pelepasan atau 
eksorsis. Di mana gereja pentakosta ini sangat berpegang pada teologi dasar Kristen dan secara khusus memiliki khotbah yang penuh semangat dan kepenuhan Roh Kudus (Ward \& Beaubrun, 1985, p. 195).

\section{Kasus Mahasiswa Yang Terikat Kuasa Okultisme di STT Abdi Sabda Medan dan Upaya Pemulihannya}

Ada beberapa penelitian terhadap mahasiswa di STT Abdi Sabda yang sudah dilayani melalui pelayanan pelepasandan akhirnya pulih dari kuasa okultisme. Kesaksian ini menceritakan tentang apa yang menyebabkan mereka terlibat dengan praktik okultisme dan apa dampak atau akibat yang ditimbulkan bagi mereka yang melakukan praktik okultisme terhadap dirinya dan terhadap keturunannya serta bagaimana upaya untuk menyembuhkan atau memulihkan seseorang agar terlepas dari praktik okultisme tersebut.

\section{Jefri Hamonangan Damanik}

Pengalaman dan kesaksian Jefri Hamonangan Damanik yang dituliskan dalam buku "Pelayanan Pelepasan dan Dampak Positifnya", Jefri adalah salah seorang mahasiswa STT Abdi Saba Medan angkatan 2012 yang pada saat itu juga dilayani dalam pelayanan pelepasan oleh tim pelayanan di STT Abdi Sabda Medan. Yang menyebabkan jefri mengalami keterikatan kuasa roh jahat adalah karena keterikatan dengan keturunan dari desa sokkur, pernah pergi ke dukun, dan juga ompung (nenek moyang) nya ada keterikatan dengan kuasa gelap. Sehingga hal itulah yang melatarbelakangi kenapa Jefri Damanik terikat pada kuasa kegelapan artinya walaupun ompung (Nenek moyang) yang melakukan tapi berdampak bagi dia sebagai pahompu (cucu) nya. Pada Februari tahun 2013 diadakan pelepasan bagi mahasiswa baru yang dilayani oleh tim pelayanan pelepasan dan dipimpin oleh Pendeta Jaharaianson Saragih. Ini pertama kalinya Jefri Damanik mengikuti ibadah pelepasan. Pada saat itu Pendeta Jaharianson dan anggota tim pelayanan membuka pelayanan dengan ibadah. Namun saat mahasiswa baru dituntun dalam bernyanyi maka Jefri Damanik mengalami manifestasi yang sangat parah. Dia tidak dapat menguasai dirinya sehingga tubuhnya dikuasai oleh kuasa Iblis dan berlangsung selama tiga jam lebih. Tim yang menyaksikannya melihat saat Jefri mengalami manifestasi ada roh yang bermanifestasi dalam tubuhnya.Yang pertama adalah roh gorilla, pada saat itu tubuhnya menunjukkan tubuh gorilla. Yang kedua adalah roh harimau, pada saat itu Jefri Damanik mencakar-cakar seperti harimau, melompat-lompat layaknya suara dan gerakan harimau.Roh yang ketiga yaitu roh orang yang sudah meninggal yang mengaku sebagai ompung (Nenek moyang) dari Sokkur. Saat itu tim pelayanan pelepasan bernyanyi dan berdoa serta memimpin melakukan doa pemutusan dan menengking roh jahat yang ada di dalam diri Jefri dan setelah dilayani kurang lebih selama tiga jam akhirnya roh jahat yang ada di dalam diri Jefri pergi walaupun demikian Jefri belum pulih dan perlu pelayanan lanjutan kepadanya.

Setelah dilayani dalam pelayanan pelepasan, Jefri sangat sering mengalami manifestasi dengan berbagai bentuk roh jahat yang ada ditubuhnya, bahkan hampir setiap hari dia mengalami manifestasi.Ini berakibat buruk pada dirinya, selain untuk kesehatannya juga nilai semesternya sangat rendah. IPK nya hanya 2,4. Itu disebabkan karena hampir setiap malam ia mengalami manifestasi sehingga waktu belajarpun sangat kurang. Ketika mengikuti ret-reat Deliverence Ministry Team di Ret-reat Center GBKP pada bulan Maret tahun 2013 Jefri dilayani secara khusus dan setelah dilayani pada saat itu Jefri mengalami pemulihan total, walaupun melalui proses yang lama sampai kurang lebih 3 jam. Setelah pemulihan total itu Jefri tidak pernah lagi mengalami manifestasi. Ia sudah merasa lebih tenang dan damai karena tidak pernah lagi diganggu roh jahat. Bahkan studinya pun sudah dapat dilakukan dengan baik serta nilai-nilai kuliahnya juga meningkat.Setelah pulih Jefri terbeban untuk melayani orang-orang yang juga terlibat kuasa okultisme. Dia bergabung di tim pelayanan pelepasan yang ada di Abdi Sabda, 
selama dua periode yaitu tahun 2014 dan 2015 dan menjadi ketua tim pelayanan pelepasan (Deliverence ministry team) di STT Abdi Sabda Medan. Setelah pulih Ia juga fokus mendoakan orang tuanya dan keluarganya agar dilayani dan dilakukan doa pemutusan. Setelah 2 tahun Jefri berdoa dan bergumul akhirnya tahun 2015 pada bulan Mei keluarganya dilayani dan didoakan sehingga keluarga Jefri sudah putus dari kuasa okultisme. Sampai saat ini Jefri aktif terlibat dalam pelayanan pelepasan dan melayani banyak orang yang terikat okultisme (Saragih, 2016, p. 380).

\section{Insan Sinurat}

Insan Sinurat adalah mahasiswa STT Abdi Sabda angkatan 2007. Awalnya ia tidak percaya akan keberadaan roh jahat dan pengaruh roh jahat terhadap kehidupan manusia. Namun setelah ia sendiri mengalaminya maka ia percaya bahwa hal itu benar ada. Pertama kali Insan Sinurat merasakan pengaruh roh jahat adalah pada bulan pertama kuliah di STT Abdi Sabda Medan. Setiap kali ia berdoa, bernyanyi, dan membaca Alkitab baik dikebaktian umum, renungan pagi dan malam kepalanya sepertinya berat, tangan terasa menjadi besar juga berat, badan sepertinya bergerak-gerak dan bayangan hitam berbentuk kepala manusia sepertinya mau menimpanya. Ia juga mendengar suara-suara yang memanggil-manggil namanya. Sehingga mulai pada saat itu Insan sinurat menjadi takut untuk berdoa, bernyanyi dan membaca Alkitab.

Keadaan Insan menjadi bertambah buruk, pada tengah malam di kost tiba-tiba ia terbangun dari tidur dan memukuli teman-teman satu kostnya.

Kejadian ini terjadi berulang-ulang sehingga teman satu kostnya menjadi heran dan takut karena tindakannya yang aneh dan suka memukuli. Ia sering tidak bisa mengendalikan emosinya bahkan ketika mereka makan tiba-tiba saja ia menendang makanan yang ada didepannya, ketika mandi ia juga memecahkan gayung dan ember. Sejak saat itu emosinya benar-benar tidak dapat dikendalikan, ia ingin marah-marah dan ingin memukul teman-teman tanpa alasan. Tidak tahan dengan tindakan Insan tadi maka teman satu kostnya membawanya ke rumah dosen yaitu Jaharianson Saragih untuk didoakan. Dalam perjalanan ke rumah dosen tiba-tiba Insan tidak bisa bicara dan bisu. Di rumah dosen Insan langsung meronta-ronta dan tidak terkendali, kekuatan bertambah sangat kuat sehingga 5 orang temannya yang memegangi tidak sanggup. Kurang lebih 3 jam didoakan akhirnya Insan sadarkan diri dan sudah bisa bicara.

Beberapa hari setelah itu saat belajar mata kuliah psikologi yang diampu oleh dosen yang sama yaitu Jaharianson Saragih tiba-tiba tanpa ada sebab Insan marah dan memukul teman disebelahnya. Dosen yang mengajar dan teman-teman sekelas terkejut dan ketakutan lalu dosen dan teman-teman sekelas mendoakannya dan setelah didoakan akhirnya dia sadar kembali. Setelah kejadian itu walaupun sudah beberapakali didoakan kondisi Insan belum pulih. Setiap kali akan berdoa, bernyanyi dan membaca Alkitab tubuhnya meronta dan memukuli teman-teman satu kost. Teman satu kost membawa Insan ke tim pelayanan pelepasan yang ada di Abdi Sabda. Di ruangan kelas Insan mulai didoakan oleh tim untuk dilayani, namun baru mulai berdoa tibatiba Insan melompat sejauh kurang lebih 2 meter ke atas dan memecahkan kursi yang didudukinya. Insan meronta-ronta dan ingin memukuli semua tim. Hampir 4 jam Insan meronta-ronta dan didoakan akhirnya sadar kembali. Namun Insan belum juga merasakan kelepasan, gangguan demi gangguan terus terjadi. Gangguan itu seperti suara memanggil-manggil namanya, sehingga membuatnya tidak bisa berdoa, tidak bisa bernyanyi dan tidak bisa membaca Alkitab. Tubuhnya sangat tertekan, ia menyadari namun tidak dapat melawan. Insan seperti diikat dengan rantai yang besar dan tidak dapat berbuat apaapa. Ia benar-benar mengalami kelelahan dan seluruh badannya sakit karena sering manifestasi dan meronta-ronta. Itulah bentuk-bentuk pengaruh roh jahat yang ada dalam dirinya, roh jahat mempengaruhi pikirannya, hati dan tindakan sehingga berperilaku demikian. 
Kelepasan dari pengaruh roh jahat atau kuasa okultisme dialami oleh Insan ketika kebaktian pelayanan pelepasan di Aula STT Abdi Sabda Medan. Dalam kebaktian itu Insan merasakan jamahan Tuhan dalam hidupnya. Dalam ibadah pelayanan pelepasan itu dia dilayani kembali dan dia juga berjuang untuk melepaskannya sehingga pada saat itu dia benar-benar lepas dari kuasa roh jahat.Insan merasakan tubuhnya menjadi ringan seperti sudah menanggalkan beban yang berat. Pikiran dan hatinya tenang dan hal ini belum pernah ia rasakan sebelumnya. Mulai saat itulah ia dapat berdoa, bernyanyi dan membaca Alkitab dengan tenang tanpa gangguan. Insan percaya kuasa Yesus mengalir dalam hidupnya dengan mengeluarkan roh jahat dalam dirinya dan menggantikannya dengan Roh Kudus.Sejak saat itu Insan tidak pernah lagi dikuasai oleh Roh Jahat.

Setelah mengalami kelepasan Insan tertarik untuk mencari tahu dan mempelajari mengapa ia mengalami kerasukan, meronta-ronta, tidak bisa bicara dan bahkan didatangi bayangan gelap serta ada suara yang memanggil-manggilnya dan sampai ia sering memukul teman-teman. Setelah diselidiki ternyata kakek Insan melakukan ritual meminta kesembuhan penyakit dengan bantuan dukun, memberikan makanan kepada anak cucunya yang sudah dipersembahkan kepada roh nenek moyang. Ayah dari Insan juga pernah meminta jimat kepada dukun berupa kulit harimau sebagai penjaga badan. Sehingga keterikatan dengan roh jahat, mulai dari kakek, ayah dan sampai kepada Insan dan itulah yang mengendalikan Insan selama ini.Hal Inilah yang melatarbelakangi Insan selama ini dipengaruhi oleh roh jahat, namun Insan beryukur akhirnya dipulihkan dan tidak lagi mengalami keterikatan dengan kuasa roh jahat.

Orang yang dipengaruhi oleh kuasa okultisme atau roh jahat akan susah mengalami pertumbuhan iman dalam Kristus karena roh jahat yang mengendalikannya dan itu jugalah yang dialami Insan sehingga ia susah berdoa, bernyayi dan membaca Alkitab. Namun sejak Insan lepas dari kuasa roh jahat ia sudah bisa menikmati ibadah, berdoa, bernyanyi dan membaca Alkitab. Setelah pulih Insan bergabung dalam tim pelayanan pelepasan dan ia menjadi ketua tim pada tahun 2011 dan sampai saat ini Insan aktif melayani dibidang pelayanan pelepasan (Saragih, 2016, p. 372).

\section{Martin Pangambatan Munthe}

Martin Pangambatan Munthe adalah mahasiswa Abdi Sabda angkatan 2008. Pada saat pelayanan pelepasan dilakukan oleh tim pelayanan pelepasan di Aula STT Abdi Sabda, Martin mengalami manifestasi. Namun doa pelayanan pelepasan yang dilakukan pada saat ia dilayani dalam pelayanan pelepasan secara massal tidak memulihkannya, karena masih ada roh jahat di dalam dirinya. Martin dilayani sebanyak 6 kali untuk menuntaskan dan membersihkanroh-roh jahat yang mempengaruhinya.

Setelah bergabung dengan tim pelayanan pelepasan pada bulan September 2008 maka diadakan doa pelepasan bagi anggota tim yang baru dan Martin salah satu yang dilayani oleh tim dan dosen pembimbing tim yaitu Jaharianson Saragih. Inilah yang pertama kali Martin mengalami doa pelepasan. Saat itu ia benar-benar menyerahkan dirinya sepenuhnya untuk didoakan agar menjadi milik Tuhan dan menutup pintu bagi iblis. Pendeta Jaharianson dan tim pelayanan menuntun Martin untuk mengaku dosa-dosa baik dosa yang berhubungan dengan kuasa gelap dan dosa moral yang selama ini tertanam di dalam hidupnya. Pada saat berdoa Martin mengalami manifestasi. Martin melihat apa yang terjadi tetapi ia tidak bisa menguasai dirinya sehingga tubuhnya dikuasai roh jahat dan mengalami manifestasi selama 2 jam. Menurut anggota tim yang menyaksikan, saat mengalami manifestasi ada 3 roh yang bermanifestasi dalam tubuhnya yaitu yang pertama roh ular, tangannya menunjukkan tubuh ular dan suara mendesis. Yang kedua, adalah roh harimau, mengaum-ngaum dan mencakar-cakar seperti harimau dan melompat-lompat layaknya suara dan gerakan harimau. Kemudian ada juga roh yang ketiga yaitu roh orang yang sudah meninggal yang 
mengaku sebagai ompung (Nenek moyang) Gumbal Munthe.Ompung Gumbal Munthe adalah Ompung kandungnya yaitu orang tua laki-laki dari ayahnya.

Tim pelayanan ada yang bernyanyi dan berdoa dan Martinpun dituntun dalam doa pemutusan dan doa pengusiran roh jahat. Martin merasa imannya yang mulai bertumbuh di dalam Tuhan dipertaruhkan dengan keadaan yang ia alami. Dua hari setelah doa pelayanan pelepasan setiap hari sekitar pukul 13.00 siang dan pukul 18.00 Martin merasakan perutnya semakin membesar layaknya perempuan yang sedang mengandung bayi. Martin bingung dengan keadaannya dan ia berpikir bahwa itu adalah suatu penyakit yang aneh. Setelah diselidiki ternyata ia belum pulih total dan masih memiliki keterikatan dengan okultisme. Kondisi itu membuat Martin minder baik di asrama dan di kampus dan ia juga harus memakai jacket jika keluar kamar asrama . Keinginan untuk sembuh membuat Martin terus berdoa, bahkan mulai berpuasa.

Melihat keadaan Martin akhirnya tim pelayanan kembali melakukan pelayanan pelepasan kepadanya dan dilakukanlah doa pelepasan yang ke dua. Seperti doa pelepasan yang pertama, Martin juga mengalami manifestasi dengan gerakan ular dan berjalan seperti ular dan roh iblis yang menyamar sebagai Ompung Gumbal Munthe juga masih merasukinya. Pelayanan kedua ini berlangsung sampai pukul 00.30 dini hari namun Martin belum juga pulih, dan melihat fisik Martin yang lemah pelayanan selesai dan dilanjutkan pada hari berikutnya.

Doa pelepasan yang ke 3 yaitu terjadi di kamar Asrama STT Abdi Sabda Meda. Saat itu Martin merasa sangat tidak nyaman karena perutnya membesar dan ia sama sekali tidak dapat berdoa. Ia dilayani oleh 8 orang tim namun pada saat itu Marti belum pulih juga. Pelayanan yang ke 4 terjadi di ruangan kantor direktur Pasca Sarjana STT Abdi Sabda Medan yang dipimpin oleh pembimbing tim yaitu Jaharianson Saragih. Doa berlangsung selama 2 jam. Setelah doa pelepasan yang keempat ia merasakan ada perubahan yang lebih baik dari sebelumnya. Doa pelepasan yang kelima pada tahun
2009 saat itu Martin kembali mengalami manifesttasi. Waktu itu ia melompat-lompat dan bergulingguling dengan jarak 3 meter, manifestasi ini tidak berlangsung lama karena sudah didorong pertumbuhan rohani dan kerinduan serta perjuangan untuk pulih sehingga Martin berusaha melawan kuasa iblis dan hal ini membuat iblis tidak dapat menguasai dirinya sepenuhnya. Setelah 5 kali mengadakan pelayanan pelepasan Martin mulai menyelidiki mengapa setiap kali didoakan ia mengalami manifestasi padahal ia sendiri tidak pernah melakukan praktik okultisme seperti perdukunan dan lain sebagainya.

Setelah diselidiki ternyata ompung (nenek moyang) Martin pernah melakukan praktik perdukunan sehingga hal itu berdampak pada keturunannya yaitu keluarga Martin. Pada bulan September 2019 Martin membawa orang tuanya untuk dilayani dan didoakan oleh tim pelayanan. Ketika orang tua Martin didoakan saat itu juga ia mengalami manifestasi. Waktu itu orang tuanya menyaksikan Martin mengalami manifestasi dan mereka menangis menyaksikan anaknya kesurupan. Namun saat itu Martin merasakan seperti berbeda dari sebelumnya, pelepasan kali ini seperti ada kekuatan yang membantunya untuk bebas dan ia percaya itu berasal dari Tuhan. Saat itu Martin dilayani beberapa jam oleh tim dan saat itulah ia benar-benar lepas dan pulih dari kuasa okultisme. Ia merasakan tubuhnya terasa sangat ringan dan ia benar-benar merasakan sukacita. Saat itu jugalah kondisinya dan keluarganya benar-benar pulih dari kuasa kegelapan. Dan akhirnya Martin bergabung dalam tim pelayanan pelepasan dan terbeban melayani orang-orang yang terikat kuasa okultisme. Dan ia juga pernah menjadi ketua tim pelayanan pelepasan di STT Abdi sabda Medan (Saragih, 2016, p. 357).

\section{Analisa}

\section{Faktor Penyebab Keterlibatan Praktik Okultisme}

Dari tiga penelitian terhadap studi kasus tersebut maka dapat dilihat apa yang menyebabkan mereka terlibat dengan praktik okultisme atau kuasa 
kegelapan. Faktornya adalah untuk kasus Jefri karena diturunkan atau diwariskan dari ompungnya sehingga berakibat ke cucu nya yaitu Jefri. Demikian juga dengan Insan Sinurat karena kakek atau nenek moyangnya dan juga ayahnya terlibat praktik okultisme yaitu memakan makanan yang sudah di persembahkan kepada nenek moyang juga ayahnya meminta jimat dari seorang dukun untuk menjaga badan yang terbuat dari kulit harimau. Demikian juga dengan Martin Munthe dikarenakan oleh nenek moyangnya yang waktu itu juga terlibat dengan kuasa kegelapan atau okultisme. Sehingga melalui ini terlihat jelas bahwa okultisme itu dapat berdampak bagi keturunan dan berakibat sangat fatal dan menyusahkan keturunan. Namun Jefri Damanik, Insan Sinurat dan Martin pangambatan Munthe bersyukur karena pada akhirnya mereka dapat pulih melaui doa pelayanan pelepasan yang dilakukan berulang-ulang kali. Martin sampai kurang lebih satu tahun dan enam kali dilayani baru pulih. Demikian juga dengan Jefri setelah beberapa kali dilayani dalam doa pelayananan pelepasan oleh tim maka barulah ia pulih bulan Maret 2013. Hal yang sama juga dialami oleh Insan Sinurat setelah beberapa kali dilayani selama kurang lebih satu tahun barulah ia pulih dari kuasa roh jahat yang menyiksanya.

Faktor pertama adalah karena faktor keturunan, yang menyebabkan Jefri Damanik, Insan Sinurat dan Martin terikat dengan kuasa okultisme adalah karena faktor keturunan, yang dimaksud faktor keturunan disini adalah dampak dari nenek moyang dan orang tua mereka yang melakukan praktik okultisme itu sendiri seperti memakai jimat yang diminta dari dukun, memakan makanan yang sudah dipersembahkan kepada berhala, menurunkan secara sengaja kekuatan-kekuatan gaib untuk menjaga badan mereka. Hal inilah yang membuat mereka terikat oleh kuasa okultisme yang memberikan dampak negatif bagi diri mereka sendiri. Dan tentunya hal ini tidak terjadi hanya bagi mereka bertiga, namun setiap orang dapat mengalaminya jika memang nenek moyang maupun orang tua pernah melakukan praktik-praktik okultisme tersebut jika tidak dipu- tuskan maka akan terus berdampak kepada keturunan selanjutnya.

Faktor kedua adalah budaya, Hutapea menyatakan bahwa budaya atau adat-istiadat dapat membuat seseorang terlibat dengan kuasa kegelapan. Sebenarnya dalam Alkitab sering sekali disinggung adat-istiadat yang bertentangan dengan Firman Tuhan (Kis.16:21), di Korintus Paulus menegur adat istiadat yang bertentangan dengan kehendak Allah (1 Kor.11:2-16). Hal ini menunjukkan bahwa iblis bisa juga memakai adat-istiadat untuk memutarbalikkan arti Firman Tuhan. Adat-istiadat dapat menjadi tempat persembunyian setan untuk menipu manusia, karena itu harus peka melihat mana adat istiadat yang harus diterangi oleh Firman Tuhan dan mana adat-istiadat yang harus terus diturunkan ke generasi berikutnya (Hutapea, 2019, p. 102). Dari ketiga studi kasus tersebut juga dapat dilihat bagaimana konteks budaya sangat mempengaruhi nenek moyang mereka untuk melakukan praktik okultisme. Secara langsung mereka bertiga tidak melakukannya namun justru orang tua dan nenek moyang mereka yang melakukannya. Budaya menyembah roh nenek moyang, budaya menurunkan kekuatan untuk penjaga badan, meminum dan memakan makanan yang sudah dipersembahkan kepada berhala, mempersembahkan korban sajian kepada roh nenek moyang. Hal-hal demikian masih melekat di dalam kehidupan secara khusus untuk konteks masyarakat Batak .Hal itu juga yang dilakukan oleh orang tua, nenek moyang mereka bertiga. Selain itu orang tua mereka juga masih terlibat dengan perdukunan karena dikalangan Batak perdukunan masih sangat kuat, contohnya dalam sebuah temuan dari penelitian Jakardo Damanik pada tahun 2010 bahwa dalam sebuah kecamatan di Simalungun terdapat 50 dukun maka jika dirata-ratakan dalam 31 kecamatan di Kabupaten itu maka terdapat 1550 dukun bahkan untuk wilayah Simalungun mereka memiliki ikatan persatuan datu (dukun) Simalungun. Itu berarti praktik okultisme dalam bentuk perdukunan masih kuat dikalangan suku Simalungun.(Damanik, 2010, p. 75) 
Sebenarnya tidak ada yang salah dengan budaya atau adat istiadat. Namun sering sekali budaya itu sendiri menjadi jalan untuk mempercayai dan melakukan praktik-praktik okultisme.Bahkan kalangan Batak secara khusus masih ada yang melakukan praktik-praktik okultisme dengan mengatasnamakan bahwa hal itu adalah budaya, seharusnya sebagai orang Kristen sudah dapat memilah mana budaya yang benar-benar murni sebagai budaya dan mana budaya yang sudah bercampur dengan praktik-praktik okultisme dan kepercayaankepercayaan terhadap roh nenek moyang yang dapat memberkati keturunannya.Oleh karena itu budaya harus diterangi oleh Firman Tuhan.

Faktor ketiga yaitu karena takut kepada roh nenek moyang yang sudah meninggal. Misalnya, takut tidak akan dilindungi roh nenek moyang, atau juga tidak diberikan berkat oleh roh nenek moyang. Sehingga membuat keturunannya menghormati roh nenek moyang dengan melakukan penyembahanpenyembahan dan ritual-ritual yang salah dan bertentangan dengan iman Kristen. Dan mereka tidak menyadari bahwa hal tersebut memberikan dampak dan akibat yang tidak baik bagi dirinya sendiri. Jadi hal ini sejalan dengan apa yang dikatakan oleh Takaliung bahwa seseorang melakukan praktik okultisme salah satu alasannya yaitu karena takut kepada amarah orang yang sudah meninggal baik itu roh nenek moyang maupun roh orang tua supaya roh yang sudah meninggal itu tidak marah terhadap anak dan cucu-cucunya yang masih hidup, tentu hal ini bertentangan dengan iman Kristen tidak seharusnya orang Kristen percaya dan melakukan hal-hal yang demikian sebab perlindungan ataupun berkat hanya berasal dari Allah bukan dari roh-roh orang yang sudah mati.

Dari apa yang mereka alami sebelum merek pulih terlihat jelas bagaimana menderitanya mereka ketika hidup mereka dikuasai oleh siiblis, bukan saja spiritualitas mereka tetapi berpengaruh juga kepada fisik, psikologi dan mental yang tersiksa tetapi juga study mereka. Dari hal inilah kita melihat betapa mengerikannya dampak atau akibat dari kuasaa ke- gelapan tersebut bagi kehidupan yang melakukan maupun bagi keturunannya.

\section{Dampak atau Akibat Praktik Okultisme Terhadap Yang Melakukan dan Terhadap Keturunannya}

Dampak atau akibat yang ditimbulkan dari praktik okultisme baik terhadap orang yang melakukannya secara langsung maupun terhadap keturunannya adalah memiliki dampak negatif yang merugikan dirinya sendiri dan keturunannya.Hal itu terjadi terhadap Jefri Damanik, Insan Sinurat dan Martin Munthe. Nenek moyang dan orang tua mereka yang melakukan praktik okultisme namun memberi dampak negatif bagi mereka akhirnya mereka mengalami penderitaan melalui sering mengalami manifestasi roh jahat, dihantui oleh rohroh jahat, menyiksa diri sendiri bahkan orang lain dengan cara memukuli orang lain, malas berdoa, tidak tahan mendengar lagu-lagu rohani, depresi, memiliki karakter pemarah, dendam, hidup di dalam ketakutan, kegelisahan, kekuatiran, tidak ada damai bahkan berdampak sampai kepada study mereka karena tidak lagi dapat fokus mengerjakan study. Bahkan tidak jarang orang yang melakukan praktik okultisme berdampak lebih fatal kepada keturunannya yaitu meminta tumbal dalam berbagai bentuk, sakit yang aneh, cacat dan gila.

Jadi benar seperti yang dikatakan oleh Hutapea bahwa setiap orang yang terlibat dengan praktik okultisme, cepat atau lambat pasti akan mengalami berbagai dampak dan akibat yang sangat buruk. Karena jika seseorang terlibat dengan kuasa gelap sesungguhnya orang tersebut sedang menyerahkan hidupnya dikuasai oleh Iblis (Yoh.8:44). Setiap orang yang terlibat praktik okultisme akan selalu dirong-rong oleh kuasa Okultisme. Dampak dari praktik okultisme mempengaruhi Pertama, secara Fisik yaitu syaraf-syaraf terganggu dan fisik tersiksa. Kedua secara Psikologi yaitu dapat mengalami depresi, ketakutan yang tidak normal, pikiran-pikiran najis, kemarahan yang tidak normal. Ketiga secara rohani yaitu mati secara rohani/ sikap tertutup terhadap Firman Tuhan, ragu-ragu terhadap Firman 
Allah dan ingin menghujat nama Tuhan. Keempat yaitu dampak bagi keturunan, akibat dari praktik okultisme bukan hanya terjadi kepada orang yang melakukannya tetapi sampai kepada keturunannya, keturunan juga akan menjadi terkutuk. Alkitab menyaksikan keturunan itu sampai kepada keturunan ketiga dan keempat (Kel.20).Kelima yaitu dampak bagi kekekalan, orang yang terlibat praktik okultisme tidak akan mendapat bagian dalam kekekalan. Firman Tuhan dalam Galatia 5:20-21 "Penyembahan berhala, sihir..ia tidak akan dapat bagian dalam kerajaan Allah". Allah memperingatkan kepada setiap umat Allah yang menduakan Tuhan akan terkutuk dan tidak berkenan kepada Allah (Ul.28:15-26).(Hutapea, 2019, p. 105)

Manifestasi roh jahat itu dapat hadir dalam berbagai bentuk kehidupan orang percaya, sehingga perlu ditinjau bagaimana kira-kira manifestasi roh jahat itu dalam kehidupan manusia. Hal ini tentu sama seperti yang dikatakan oleh Annacondia bahwa manifestasi roh jahat itu terlihat berbeda dalam orang yang berbeda, seperti orang yang tertekan, orang yang kerasukan, dan orang gila.(Annacondia, 2005, p. 59). Itulah sebabnya setiap orang percaya harus dapat melihat dan memilah dengan jelas pekerjaan-pekerjaan iblis didalam kehidupan orang percaya. Dan satu hal yang pasti bahwa ketika seseorang melakukan praktik okultisme maka akan berakibat buruk terhadap dirinya sendiri dan terhadap keturunannya dan akibat buruk itu dapat pulih jika mereka mau memutuskan keterikatan dengan kuasa okultisme tersebut.

\section{Upaya Yang Dapat Dilakukan Untuk Menyembuhkan dan Memulihkan Seseorang Agar Terlepas dari Kuasa Okultisme}

Apa yang dipaparkan diatas adalah hal yang dialami juga oleh Jefri, Insan dan Martin. Mereka tertekan secara psikologis, secara fisik juga secara rohani, akibat dari kuasa okultisme itu membuat mereka sangat menderita namun mereka akhirnya pulih atau sembuh setelah dilayani melalui doa pelayanan pelepasan oleh tim doa pelepasan. Disinilah dapat dilihat bahwa pelayanan pelepasan bagi mereka yang berada dibawah kuasa okultisme baik itu karena faktor keturunan atau yang diwarisi oleh nenek moyang maupun karena keterlibatan langsung penting untuk serius ditangani melalui pelayanan pelepasan atau yang lebih sering disebut dengan eksorsisme. Kasus yang terjadi di Afrika yang dialami oleh empat orang tersebut juga berkaitan dengan kasus-kasus kerasukan psikodinamik dan akhirnya mereka juga dilayani melalui pelayanan eksorsisme di gereja Pentakosta Trinidad. Bahkan mereka ada yang dilayani sampai beberapa kali, seperti Sonia dilayani melalui pelayanan eksorsis selama 32 kali, Salina 100 kali, Phil sebanyak tiga kali dalam tiga bulan, dan Nan sebanyak 3 kali dalam waktu dua bulan.

Seperti yang dikatakan oleh Twelftree bahwa pelayanan eksorsisme adalah penyembuhan yang dilakukan ketika setan atau roh jahat masuk dalam tubuh seseorang, dan eksorsisme merupakan sebuah upaya untuk mengontrol atau mengusir roh jahat yang mendiami seseorang tersebut.(Twelftree, 1993, p. 11), maka dari itu jelas bahwa ketika seseorang terikat dengan kuasa okultisme seharusnya upaya yang dilakukan adalah melakukan pelayanan eksorsisme supaya mereka yang terikat dengan kuasa okultisme dapat pulih dan tidak lagi mengalami penderitaan karena dampak dari okultisme tersebut.

Selain itu ketika pelayanan eksorsisme dilakukan bagi seseorang yang terikat okultisme dan mengalami pemulihan, hal itu juga sebagai pertanda hadirnya kerajaan Allah. Itu berarti eksorsisme menjadi pembuktian bahwa kerajaan Allah telah hadir atau sedang hadir di bumi. Pengusiran setan-setan menunjukkan bahwa misi Yesus sedang terjadi, teraktualisasi, dan digenapi. Sehingga eksorsisme yang dilakukan Yesus bukan hanya menyembuhkan dan mengusir kuasa setan dari diri manusia tetapi juga menunjukkan bahwa kerajaan Allah sedang beroperasi (Twelftree, 1993, p. 168). Dan Twelftree juga menyebut dengan kata lain pelayanan eksorsisme berarti mendemonstrasikan bagi kita bahwa eskatologi sudah hadir di dalam diri Yesus. 
Demikian juga dengan pengusiran Setan/ iblis dalam diri manusia memiliki makna bahwa zaman Mesias sudah hadir.Oleh karena itu dengan eksorsisme yang diperlihatkan Yesus membuktikan bahwa Dialah Mesias sesungguhnya yang dinubuatkan dalam perjanjian Lama. (Twelftree, 1993, p. 217)

Jadi pelayanan eksorsisme yang dilakukan Yesus bukan bermaksud hanya untuk mengusir, mendesak setan keluar dari diri manusia melainkan dengan eksorsisme itu sendiri Yesus sedang memproklamasikan kerajaan Allah atau kerajaan sorga sudah hadir di tengah-tengah mereka. Pemaknaan seperti ini tidak ditemukan dalam pelaksaan eksorsisme lainnya, kitab Matius jelas menyebutnya: "Tetapi jika Aku mengusir setan dengan kuasa Roh Allah, maka sesungguhnya kerajaan Allah sudah datang kepadamu"(Mat.12:28, Luk.11:20). Dari pemaknaan ini nyata eksorsisme yang dilakukan Yesus memiliki makna yang jauh lebih dalam dari eksorsisme lainnya.

Jadi ketika Yesus melakukan eksorsisme, orang yang dirasuk setan berhadapan secara langsung dengan kekuatan (power ecounter) (Twelftree, 2007, p. 46). Dan dalam Kehidupan orang Yahudi untuk mengusir roh jahat masih bergantung dengan pelaksanaan ritual misalnya dengan menggunakan sarana membakar hati dan jantung ikan. Sementara Yesus secara langsung menghardik Iblis , misalnya dengan mengatakan: "Diam, keluarlah dari padanya" (Mrk.1:25). "Hai engkau roh jahat, keluarlah dari orang ini” (Mrk.5:8, 9:25), bahkan Yesus juga menanyakan namanya: "Siapakah namamu, jawabnya: namaku: Legion, karena kami banyak" (Mrk.5:9). (Soresen, 2002, p. 128).

Pelayanan pelepasan atau eksorsisme tidak hanya bertujuan supaya manusia mengalami kelahiran kembali atau menerima kerajaan surga. Pelayanan pelepasan juga akan membuat manusia mengalami pemulihan secara fisik. Pelayanan pelepasan juga akan menyembuhkan penyakit fisik akibat okultisme, menghilangkan rasa takut dan juga meningkatkan kehidupan rohani setiap orang yang telah menikmati pelayanan pelepasan tersebut (Hutapea, 2019, p. 119)

Doa dan pelayanan pelepasan adalah cara yang efektif untuk membantu mereka yang terlibat dengan kuasa okultisme. Banyak yang sudah dilayani melalui doa pelayanan pelepasan akhirnya pulih dari kuasa okultisme dan tidak lagi berada dibawah kuasa okultisme. Namun perlu dipahami bukan pelayanan pelepasannya yang berkuasa namun kuasa di dalam nama Tuhan Yesus itu yang memulihkan dan membebaskan mereka yang terlibat kuasa okultisme menjadi pulih. Jika ditanya, mengapa doa pelayanan pelepasan dapat memutuskan kuasa okultisme terhadap seseorang? Tentu jawabannya ialah karena doa itu dilakukan di dalam nama Tuhan Yesus yang memiliki kuasa yang besar untuk memutuskan kuasa okultisme dari seseorang yang berada dibawah kuasa tersebut.

Dalam pelayanan pelepasan itu, orang yang melayani sebaiknya tidak hanya melakukan pengusiran setan-setan melainkan juga berusaha membuat analisis kehidupan konseli tentang bagaimana latarbelakang keterikatan konseli itu terhadap okultisme, setelah itu dilakukan follow up untuk membimbing klien semakin intim dengan Tuhan. (Simanjuntak, 2008, p. 69) Dengan cara demikian maka klien akan mengalami pertumbuhan iman didalam Tuhan dan benar-benar mengalami pemulihan.

Yesus sendiri melakukan pelayanan eksorsisme untuk menolong orang-orang yang terikat kuasa okultisme pada saat itu untuk pulih, sebab pada saat itu mereka yang terikat kuasa okultisme tidak hanya menderita secara psikologi tetapi juga secara fisik. Contoh dua praktik eksorsis yang dilakukan oleh Tuhan Yesus adalah penyembuhan putri dari perempuan Siro-Fenesia (Mat.15:12-28 dan Mrk. 7:24-30) dan juga perempuan yang punggungnya bengkok (Luk.13:11-13). Menurut Matius putri dari perempuan Siro-Fenesia itu dirasuk setan dan Markus juga mengatakan catatan mengenai setan yang satu itu dan menyebutnya roh jahat, dan hal inilah satu-satunya mengenai kisah eksorsis dalam 
jarak jauh. Dan Yesus digambarkan dalam kitab Injil sebagai eksorsis sejati.(Brewer, 1996, p. 133). Dalam Perjanjian Baru juga banyak data yang mencatat tentang pengusiran setan, sehingga peristiwa yang berkaitan dengan pengusiran setan atau eksorsisme seperti yang dilakukan Yesus dan para murid dalam Perjanjian Baru dapat diambil sebagai dasar dari pelayanan pelepasan.(Sutoyo, 2015, p. 3) Dalam sebuah artikel mengenai "Okultisme dalam Pelayanan Pelepasan" dikatakan bahwa pelayanan penggembalaan dikalangan gereja-gereja seringkali kurang memperhatikan pelayanan pelepasan dari kuasa-kuasa roh jahat.Sementara jemaat Tuhan juga tidak mengerti atau tidak tahu bahwa ada roh jahat sedang bekerja diantara mereka. Itulah sebabnya pelayanan okultisme dalam pelayanan penggembalaan sangat penting dilakukan dan hambahamba Tuhan harus siap membela umat Tuhan dengan melawan iblis dengan iman yang teguh sehingga umat-umat Tuhan bisa lepas dari kuasa iblis yang membelenggunya.(Juld \& Enoh, 2013, p. 189) Praktik pengusiran setan merupakan hal yang alkitabiah dan masih terus dapat dipraktikkan dalam kehidupan bergereja sampai saat ini. Alkitab menyatakan bahwa Allah memberikan kuasa kepada gereja-Nya untuk menaklukkan kuasa iblis melalui berbagai bentuk pelayanan termasuk dalam pengusiran setan. Lukas 4:31-37 dengan sangat jelas menyatakan bagaimana Yesus melakukan pelayanan pengusiran setan kepada para murid dan semua orang percaya.(Prabowo, 2017, p. 81)

Masalah okultisme bukanlah merupakan pengajaran yang baru bagi orang Kristen, karena Alkitab jelas menyatakan pekerjaan Iblis dalam berbagai manifestasi dan salah-satunya adalah praktik okultisme. Pekerjaan Iblis tidak hanya menggoda dan menyesatkan manusia tetapi menawarkan pertolongan sesuai yang dinginkan manusia dengan cara yang tersembunyi sehingga banyak orang yang tidak menyadari bahwa mereka telah diperdaya dan diikat oleh kuasa iblis karena iblis tidak pernah menolong tanpa merongrong atau menuntut imbalan. Ini adalah tugas gereja dan orang percaya untuk membuka diri terlibat di dalam pelayanan pelepasan atau eksorsisme dan sekaligus memperlengkapi diri dengan pemahaman tentang okultisme, sehingga siap untuk melakukan peperangan rohani dan melakukan pelayanan pelepasan kepada jemaat yang masih terlibat dengan kuasa kegelapan atau okultisme.

Orang percaya sebagai murid Kristus penting meneladani Yesus Kristus dalam melakukan pelayanan terhadap mereka yang terlibat kuasa okultisme atau kuasa Iblis. Dalam kehidupan pelayananNya Tuhan Yesus tidak hanya mengajar tentang Firman Allah pada saat itu, tetapi ia juga menyembuhkan banyak orang sakit baik mereka yang sakit secara fisik maupun mereka yang sakit secara rohani. Yesus menyembuhkan banyak orang dan mengusir setan-setan dari orang-orang yang di rasuk oleh roh jahat, kapan dan dimanapun bahkan di rumah ibadat sekalipun Yesus mengusir setan pada saat itu (Mark.1:34,35). Namun Yesus tidak hanya menghentikan kuasa itu pada diri-Nya tetapi Yesus juga memperlengkapi dua belas murid dan mengutus mereka serta memberi kuasa kepada mereka untuk mengusir setan dalam nama-Nya (Mark.3:14-15). Bahkan setiap orang yang percaya kepada Kristus sesungguhnya dapat mengusir setan di dalam namaNya, "Tanda-tanda ini akan menyertai orang-orang percaya: mereka akan mengusir setan-setan demi nama-Ku, mereka akan berbicara dalam bahasabahasa yang baru bagi mereka".

Jefri Damanik dari hasil penelitiannya terhadap 15 orang mahasiswa Abdi Sabda yang terikat okultisme dan sudah dilayani dalam pelayanan pelepasan mengatakan bahwa setelah mahasiswa dilayani melalui pelayanan pelepasan dan dilakukan follow up untuk memperhatikan kerohaniannya maka dampak positif dari pelayanan pelepasan itu adalah spiritualitas mahasiswa tersebut menjadi sangat baik dan bertumbuh, setelah dilayani mereka menjadi rajin saat teduh, berdoa dan membaca Alkitab. Bahkan mereka akhirnya tergabung dalam tim pelayanan pelepasan di Abdi Sabda untuk melayani orang-orang yang terikat okultisme sama se- 
perti mereka sebelumnya.(Damanik, 2017, p. 126). Jadi pelayanan pelepasan sangat penting dilakukan kepada orang-orang yang terlibat dalam kuasa okultisme atau kegelepan dengan berbagai manifestasinya, karena jika tidak dilakukan maka roh jahat atau kuasa-kuasa iblis itu akan membawa seseorang semakin jauh dari Tuhan dan menjadi budak iblis. Seperti pelayanan yang sudah dilakukan oleh STT Abdi Sabda Medan, dimana setiap tahun diadakan pelayanan pelepasan bagi mahasiswa baru baik juga bagi mahasiswa lama yang mau dilayani termasuk jemaat atau orang dari luar kampus yang bersedia untuk dilayani. Tentu apa yang sudah dilakukan oleh STT Abdi Sabda tersebut adalah sebuah awal yang baik untuk dilihat oleh berbagai gereja atau para pelayan Tuhan. Sebab pelayanan pelepasan adalah upaya yang dapat dilakukan untuk menyembuhkan atau memulihkan seseorang agar terlepas dari praktik okultisme.

\section{KESIMPULAN}

Jawaban dari hasil penelitian ini adalah ada tiga faktor yang menyebabkan orang terikat dengan okultisme yaitu faktor keturunan, budaya dan karena takut terhadap roh nenek moyang yang sudah meninggal. Dan akibat keterikatan terhadap okultisme tersebut membuat mereka menderita baik secara fisik, psikologi bahkan study. Namun mereka dapat pulih setelah dilakukan pelayanan eksorsisme beberapa kali dan juga follow up untuk menolong mereka agar benar-benar pulih dan mengalami pertumbuhan iman kepada Tuhan.

\section{DAFTAR RUJUKAN}

Alwi, H. (1987). Kamus Besar Bahasa Indonesia. Jakarta: Balai Pustaka.

Annacondia, C. (2005). Dengarkan Saya, Setan! (Terjemahan). Jakarta: Varvest Publication House.

Brewer, D. I. (1996). Jesus and The Psychiatrists. Baker Book House: Paternoster Press.
Orang Kristen dan lembaga gereja juga harus benar-benar serius menolong orang yang terikat okultisme dengan cara melakukan pelayanan eksorsisme kepada mereka. Gereja harus melihat dan meneladani Yesus Kristus sang kepala gereja yang juga melakukan pelayanan eksorsisme kepada orang-orang yang dirasuk roh jahat pada saat itu. Dengan melakukan pelayanan eksorsisme maka gereja juga sedang menghadirkan kerajaan Allah di dunia ini.

Karena itu saran penulis sebaiknya lembaga Gereja, Sekolah Tinggi Teologi (STT), juga universitas Kristen yang memiliki Fakultas Teologi dapat meneladani STT Abdi Sabda yang memberi perhatian khusus bagi mereka yang terikat dengan kuasa okultisme. STT Abdi sabda sendiri bahkan membentuk tim pelayanan khusus yang fokus melayani orang-orang yang terikat dengan kuasa okultisme baik didalam kampus maupun diluar kampus. Dan sebaiknya kampus maupun lembaga Gereja juga memberi perhatian terhadap orang-orang yang terikat dengan kuasa okultisme dengan cara membentuk tim pelayanan khusus, selain itu kampus dan gereja juga sebaiknya memberikan pemahaman mengenai okultisme, dampak dari okultisme dan bagaimana upaya yang dilakukan untuk memulihkan orang yang terikat dengan kuasa okultisme. Pemahaman ini dapat dilakukan melalui seminarseminar yang dilakukan kampus maupun Gereja dengan tujuan agar semakin banyak orang yang memahami dampak dari okultisme tersebut sehingga mereka tidak lagi terlibat terhadap praktik-praktik okultisme.

Damanik, Jakardo. (2010). Pendukunan Ditinjau dari Iman Kristen. Medan: Skripsi: STT Abdi Sabda.

Damanik, Jefri. (2017). Eksorsisme (Suatu Tinjauan Teologis Praktis Terhadap Dampak Pelayanan Eksorsisme Bagi Kehidupan Rohani Mahasiswa STT Abdi Sabda Medan). Medan: Skripsi: STT Abdi Sabda. 
Hutapea, J. (2019). Okultisme: Penuntun Praktis Mengenali dan Melepaskan Dari Kuasa Kegelapan. Medan: Vanivan Jaya.

Juld, R. J., \& Enoh, I. K. (2013). Okultisme dalam Pelayanan Pastoral. Jurnal Theologi: STT Jaffray, 11, No. 2.

Krisnando, D., Objantoro, E., \& Darmawan, I. P. A. (2019). Konsep Teologi Injili Tentang Roh Orang Mati. Evangelikal: Jurnal Teologi Injili dan Pembinaan Warga Jemaat, 3(1), 90-99.

Kusuma, J. S. (2010). Okultisme: Antara Budaya vs Iman Kristen. Yogyakarta: ANDI.

Pasaribu, R. H. (2002). Okultisme Dikalangan Masyarakat Batak. Jakarta: PT. Atalya Pileni Sudico.

Pondsius, \& Takaliung, S. (n.d.). Pondsius \& Susanna Takaliung, Antara Kuasa Gelap dan Kuasa Terang, Malang: Literatur YPPI, 1987. Malang: Yayasan PPII.

Prabowo, Y. S. (2017). Implementasi Pelayanan Pengusiran Setan Menurut Lukas 4:31-37 Pada Gereja Masa Kini. Antusias: Jurnal Teologi Dan Pelayanan, 5 No.1, 57-82.

Prience, D. (2002). Mereka Akan mengusir Setansetan. Jakarta: yayasan Pekabaran Injil.

Sappington, T. J. (1998). Hancurkan Kuasa Iblis Dalam Diri Anda. Jakarta: ANDI.

Saragih, J. (2016). Pelayanan Pelepasan dan Dampak Positifnya. P. Siantar: L-SAPA.
Simanjuntak, J. (2008). Konseling Gangguan Jiwa \& Okultisme: Membedakan Gangguan Jiwa dan Kerasukan Setan. Jakarta: Gramedia.

Soresen, E. (2002). Possesion and exorcism in the New Testament and Early Christianity. Tubengen: J.C.B.Mohr.

Spencer, H. (2009). Herbet Spencer, Principles of Sociology Vol I (1876), London : Forrgotten Book's, 2009. London: Forgotten Book's.

Sutoyo, D. (2015). Pneumatologi Lukas: Pemberdayaan Pelayanan Kristen. Antusias: Jurnal Teologi Dan Pelayanan, 4 No.7, 133.

Twelftree, G. H. (1993). Jesus the Exorcist A Contribution to Study of the Historical Jesus. Tubingen: J.C.N. Mohr.

Twelftree, G. H. (2007). In the Name of Jesus Exorcism Among Early Christian. Mic. Baker Academic: Grand Rapids.

Ward, C. A., \& Beaubrun, M. H. (1985). Collen A Ward, dan Michael H. Beaubrun, The Psycodynamic of Demon Possesion. Dalam Jurnal: Arthur C. Lehmann and James E. Myers, Magic, Witchraft and Religion An Anthropological Study of The Supernatural. California: Mayfiled Publishing Company.

Wulfhost, I. (2005). Ancestor, Spirit and Healing in Africa and Asia A Challenge to the Church. Switzerland: The Lutheran WorldFederation. 